\title{
Serum Immunoglobulins and complement subfactors levels in sodium valproate treated epileptic patients
}

Dr. Imad Abdul-Jabbar Thanoon*, Omer AH Ahmed**, Mohammed Khalid Al-Nori***, Nazar A-K Hami****

Departments of Pharmacology*, Surgery****, Mosul College of Medicine, Departments of Clinical Pharmacy**, biochemistry***, College of Pharmacy; University of Mosul, Iraq

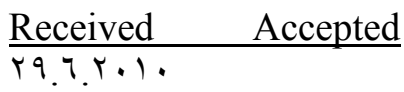

$r \cdot .1 \cdot r \cdot 1 \cdot$

ABSTRACT

Objectives: To assess, the serum levels of immunoglobulins (IgG, IgA, IgM) and complement subfactors $\left(\mathrm{Cr}^{r}, \mathrm{C} \varepsilon\right)$ in newly diagnosed epileptic patients in the pretherapy stage and $r$ months after valproate therapy, in comparison with controls.

Methods: This study was conducted at Iben-Seena Hospital and the College of Medicine- University of Mosul from January to December $Y . .9$. Forty-two newly diagnosed epileptic patients were selected and included in this study. Fifty apparently healthy subjects, age and sex matched to the patients group also included and taken as a control. Initially from both the patients and controls, blood samples were taken and assessment of sera levels of immunoglobulins and complement subfactors were done by single radial immuno diffusion method, using commercial kits. Then patients were put on valporate therapy for $r$ months and a blood sample were taken from the patients and assay of the same parameters mentioned above were done using the same technique and the same kits.

Results: There were insignificant differences between patients in pre-therapy stage and controls with regard serum immunoglobulin levels (and complement subfactors). Also there were insignificant differences between epileptic patients before and $r$ months after therapy with valproate .

Conclusion: valproate as an anticonvulsant have no influence on serum immunoglobulin (IgG, $\operatorname{IgA}, \operatorname{IgM})$ and complement subfactors $\left(\mathrm{Cr}^{r}, \mathrm{C} \varepsilon\right)$ after $r$ months of therapy.

Key Words: newly diagnosed epileptic, valproate therapy, immunoglobulin and complements subfactors levels.

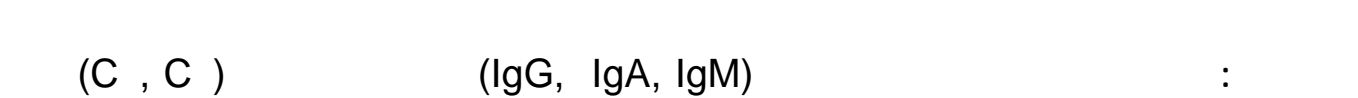

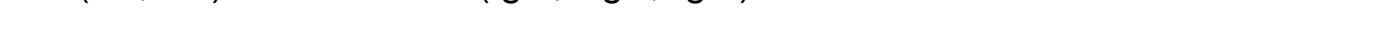
الضط.

طرالق العلى: تمت هذه الدرلسه في مستثفى ابنسينا وكلية الطب -جلمعة الموصل للفتره من كالنون ثاني

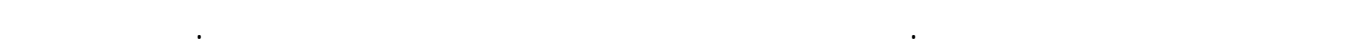

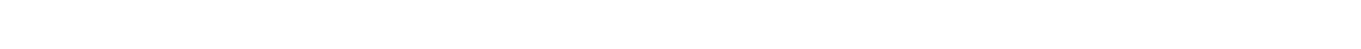

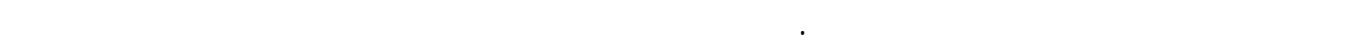

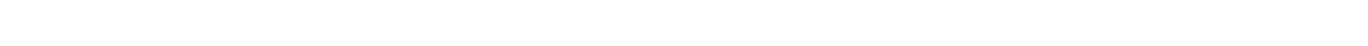

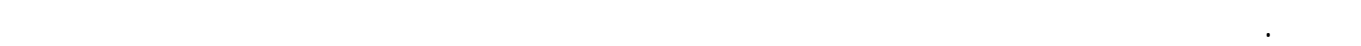

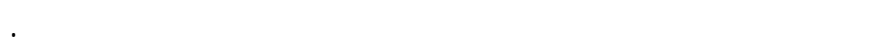

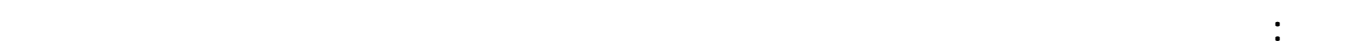

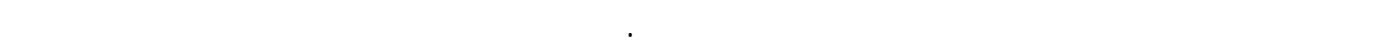

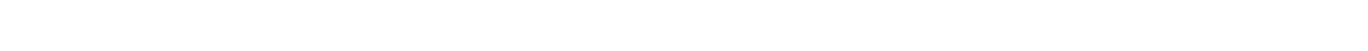

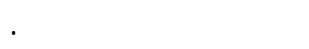


الاستنتاج: ان عقار الفالبروات كمضاد اللصرع لايحل أي تأثير عله مستوى الكلوبيولينات المناعيه

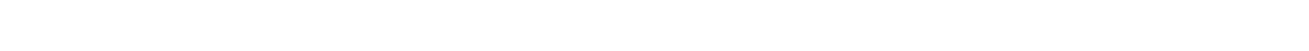
University of Mosul, Iraq). Patients W pilepsy is a common neurological clinicians for many centuries'. However little is known about the aetiology of the disease, but among many mechanisms proposed, the immunological one have been implicated as an aetiological factor of epilepsy, especially in children with intractable epilepsy ${ }^{\top}$. Certain clinical studies suggested that aberrations of the immunologic system may be associated with untreated epilepsy and with the use of anticonvulsant therapies ${ }^{r, r}$.

Immunoglobulin A $(\lg \mathrm{A})$ deficiency has been detected in up to ro\% of patients with epilepsy ${ }^{\varepsilon}$, and the most frequent abnormality is a reduction in serum and salivary $\operatorname{IgA}$ concentration which occurs in about one-fifth of epileptic patients receiving diphenhydantoin ${ }^{\circ}$. On the other hand, disturbances of immunoglobulin $\mathrm{G}$ and M ( IgG, IgM) levels have also been reported, but the results are conflicting since both increased and decreased concentrations have been found ${ }^{\circ,}$. The complements are cascading series of plasma enzymes and effector proteins whose function is to lyse pathogens and or target them to be phagocytized by phagocytic cells of the reticuloendothelial system ${ }^{\vee}$.

The aim of this study is to assess the immunoglobulin levels and complement subfactors in newly diagnosed epileptic patients before therapy and $r$ months after valproate therapy in comparison to control.

\section{Patients and methods}

This study was conducted from January to December $r . .9$. Approval have been obtained from ethical committee (the main health centre in Mosul and Mosul College of Medicine, were selected according to certain criteria.

\section{Criteria for selection}

1. Newly diagnosed patients with epilepsy (clinical diagnosis was made by neurologist).

$r$. Selected for valproate monotherapy for the initial $r$ months.

$r$. No coexisting renal, hepatic, thyroid dysfunction, nor diabetes or any disease of suspected immunological basis.

¿. Compliant patient.

Of the patients interviewed only $\leqslant \wedge$ were eligible for enrollment in the study according to the criteria mentioned above and only $\leqslant r$ completed the study. They were ir females and $r \cdot$ males with a mean \pm SD age $r$ r.A. \pm 0.11 years (ranged between $i \wedge$ and $r \wedge$ years). Also included (O.) apparently healthy subjects as a control group. They were ( $) \varepsilon$ ) females and ( $r$ ) males with a mean $\pm S D$ age $r v . \cdot r \pm 0.0$ years (ranged between $i \wedge$ and $r \wedge$ years). Initially from both the patients and controls, ${ }^{\circ} \mathrm{ml}$ venous blood samples were taken and assessment of immunoglobulin levels (IgG, IgA, IgM) and complement subfactors $\left(\mathrm{C}^{\mathrm{r}}, \mathrm{C} \varepsilon\right)$ were done by single radial immunodiffusion method $^{(\wedge)}$ using kits from Sanofi diagnostics Pasteur (France). For the patients group, they were put on valproate therapy in a mean \pm SD dose $\leqslant 0 v .1 \leqslant \pm 1 \cdots, r r \mathrm{mg} / \mathrm{dL}$ (ranged between $\leqslant \cdots m g$ and $\wedge .$. $\mathrm{mg} / \mathrm{dl}$ ) for $r$ months, by the end of which another blood samples were taken and assessment of the same parameters mentioned above were done.

Standard statistical methods were used to determine the mean ,standard deviation (SD) and the range. Paired ttest was used to compare the results of 
the patients in the pre and post-therapy stage. Unpaired t-test was used to compare the results of the patients in the pre-therapy stage and the controls. $P<\bullet . \bullet$ was considered to be statistically significant.
There were insignificant differences between epileptic patients in the pretherapy stage and the controls with regard serum immunoglobulin levels (IgG, IgA, IgM) and complement subfactors $\left(\mathrm{Cr}^{\mathrm{r}}, \mathrm{C} \varepsilon\right)$ as shown in Table 1

\section{Results}

Table 1. Comparison of immunological classes and complement subfactors in pretherapy epileptic patients and control.

\begin{tabular}{|c|c|c|c|}
\hline $\begin{array}{c}\text { Parameter } \\
\text { Immunoglobulins } \\
\text { and complements } \\
\mathrm{g} / \mathrm{L}\end{array}$ & $\begin{array}{c}\text { Patients pre-therapy } \\
\mathrm{No}=\varepsilon r \text { mean } \pm \mathrm{SD}\end{array}$ & $\begin{array}{c}\text { Controls } \mathrm{No}=0 \cdot \\
\text { mean } \pm \mathrm{SD}\end{array}$ & $P$ value \\
\hline $\operatorname{IgG}$ & $1 \cdot . v \leq \pm 1.1 v \varepsilon$ & $1 \cdot . \Sigma T r \pm 1 . r T \varepsilon$ & $>\cdot .0$ \\
\hline IgA & $r . Y Y \wedge \pm \cdot . r 0 \leq$ & $r . r \cdot T \pm \cdot . r T V$ & $>\cdot .0$ \\
\hline $\operatorname{IgM}$ & $1 . \leqslant 9 \cdot \pm \cdot . r 1 \leqslant$ & $1 . \leqslant \wedge r \pm \cdot . r)$. & $>\cdot .0$ \\
\hline $\mathrm{C}^{\mu}$ & $r .0 V \pm . .197$ & $r \cdot \varepsilon \tau \pm \cdot r \cdot \varepsilon$ & $>\cdot .0$ \\
\hline $\mathrm{C} \varepsilon$ & $.970 \pm . .09$ & $. r 4 . \pm \cdot .0 r$ & $>\cdot .0$ \\
\hline
\end{tabular}

There were insignificant differences between patients in the pretherapy and post-therapy stages with regard serum levels of immunoglobulin levels (IgG, $\operatorname{IgA}, \operatorname{IgM})$ and complement subfactors $(\mathrm{Cr}, \mathrm{C} \varepsilon)$. Table $(r)$

Table $r$. Comparison of immunological classes and complement subfactors in epileptic patients in the pre and post-therapy stage.

\begin{tabular}{|c|c|c|c|}
\hline $\begin{array}{c}\text { Parameter } \\
\text { Immunoglobulins } \\
\text { and } \\
\text { Complements } \\
\text { g/L }\end{array}$ & $\begin{array}{l}\text { Patients pre-therapy } \\
\text { mean } \pm \text { SD }\end{array}$ & $\begin{array}{l}\text { Patients post-therapy } \\
\text { stage mean } \pm \text { SD }\end{array}$ & $\mathrm{P}$ value \\
\hline $\operatorname{IgG}$ & $1 . . v \leq \pm 1.1 v \leq$ & $1 \cdot . \wedge 0 V \pm 1.1 \leqslant \varepsilon$ & NS \\
\hline $\operatorname{IgA}$ & Y.YYA \pm . YOS & $r . r_{0} \pm \cdot r \cdot q$ & NS \\
\hline $\operatorname{IgM}$ & $1 . \leqslant q \cdot \pm \cdot . r) \leqslant$ & $1.0 . \varepsilon \pm . .110$ & NS \\
\hline $\mathrm{Cr}^{\mathrm{N}}$ & $r .0 V \pm . .197$ & $r . \cdot \leq 1 \pm \cdot .191$ & NS \\
\hline$C \varepsilon$ & $.1470 \pm . .09$ & $. .4 T \pm . .01$ & $\mathrm{NS}>\cdot . \cdot 0$ \\
\hline
\end{tabular}




\section{Discussion}

Our study revealed insignificant differences between newly diagnosed epileptic patients before starting therapy and the control with regard serum levels of immunoglobulins (IgG, IgA, IgM) and complement subfactors $\left(\mathrm{C}^{\mathrm{r}}, \mathrm{C} \varepsilon\right)$, also there was insignificant differences between patients in pretherapy and post-therapy stages with regard serum levels of immunoglobulin (IgG, $\operatorname{IgA}, \operatorname{IgM}$ ) and complements $\left(\mathrm{Cr}^{r}, \mathrm{C} \varepsilon\right)$.

In I $9 \vee \vee$ Joubert et al, reported that epileptic patients on valproate therapy had mean serum IgA levels significantly lower than non-users of valproate ${ }^{q}$. In agreement with our study Lenti et al. evaluated serum immunoglobulins in to epileptic children treated with anticonvulsants (carbamazepine and valproic acid), IV untreated patients and is healthy subjects. The treated and untreated patients did not differ significantly from the controls with respect to the mean IgA , IgG and IgM serum levels, and concluded that there were no major changes in immune status related to clinical type of epilepsy or to carbamazepine or valproate therapy'. Bostantjopoulo et al. " studied 0 . epileptic patients ( $\uparrow$. without medication, 10 on carbamazepine and 10 on valproic acid ) and $r$. healthy controls. They reported that the untreated epileptic group had increased levels of $\operatorname{IgA}$ and $\operatorname{IgG}$, patients on carbamazepine showed increased IgG and $\operatorname{IgM}$ levels, while patients on valproate had increased levels of IgM. Basaran et al. studied the humoral and cellular immune parameters in untreated and phenytoin or carbamazepine treated epileptic patients and noticed that patients on phenytoin had decreased serum IgA and $\operatorname{IgG}$ levels, while those on carbamazepine had decreased serum IgM levels and untreated epileptic showed immune profiles significantly different from healthy subjects suggesting that epilepsy per se may be associated with certain immune aberrations induced by antiepileptic drugs "r. The complement system and immunoglobulins are the main components of humoral immunity . The activation of complement is known to be involved in a number of forms of cardiovascular disease, such as exacerbation of myocardial defect following ischaemic injury and may be involved in the degeneration of spontaneous atherosclerotic lesions "r. This might be the first study concerning levels of complements $\left(\mathrm{Cr}^{r}, \mathrm{C} \varepsilon\right)$ in epileptic patients before and after valporate therapy.

In conclusion, our study concluded that valproate as an antiepileptic drug did not have a significant effect on serum immunoglobulins ( $\operatorname{IgG}, \operatorname{Ig} \mathrm{A}$, IgM) and complement subfactors $\left(\mathrm{C}^{\top}, \mathrm{C} \varepsilon\right)$ levels in epileptic patients.

\section{References}

1. Maurice V, Allan HR. Epilepsy and other seizure disorders in: Adams and Victors Principles of Neurology. Mc Graw- Hill r. . I: $r \leqslant 9$.

r. Eeg- Olofsson O, Bergstorm T, Osterland CK, Andermann F, et al. Epilepsy etiology with special emphasis on immune dysfunction and neurovirology. Brain Dev 1990;1V suppl:s01_7.

ґ. Aarli JA. Immunological aspects of epilepsy. Brain Dev 1994; 10(1): $\leqslant 1-9$. 
ร. Bouma PA. Determining prognosis of childhood epilepsies by establishing immune abnormalities.

- Andersen P, Mosekildel L. Immunoglobulin levels and auto antibodies in epileptics on long term anticonvulsant therapy. Acta

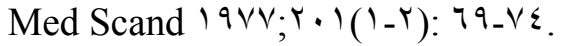

7. Aarli JA, Tonder O. Effect of antiepileptic drugs on serum and salivary $\operatorname{IgA}$. Scand $\mathrm{J}$ Immunol

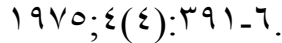

$\checkmark$. Haynes BF, Fauci AS. Disorders of the immune system. In: Harrison's Principles of Internal Medicine, $10^{\text {th }}$ ed. Braun WE, Hauser SL, Fauci AS, Longo DL, Kasper DL, Jameson JL editors. Mc Graw-Hill company. USA. PP:r • । - .

^. Mancini G, Carbonara AO, Heremans JF. Immunochemical quantitation of antigens by single radial immunodiffusion. Immunochem 1970;Y:Yro_os.

१. Joubert PH, Aucamp AK, Potgieter GM, Verster F. Epilepsy and IgA deficiency.The effect of sodium
Clin Neurol neurosurgery $1994 ; 9 \varepsilon$ suppl: so ${ }^{0}-7$.

valproate. $\mathrm{S}$ Afr Med J 19VV;OY (1 T):T $\{r-\varepsilon$.

1. Lenti C, Masserini C, Peruzzi C, Guareschi CA. Effects of carbamazepine and valproate on immunological assessment in young epileptic patients. Ital $\mathrm{J}$ Neurol Sci $1991 ; 1 Y(1)$ :^V_q1.

11. Bostantjopoulou S, Hatzizisi O, Argyropoulou O, Andreadis S, etal. Immunological parameters in patients with epilepsy. Funct Neurol $199 \leqslant ; 9(1): 11$ _.

1r. Basaran I, Hincal F, Kansu E, Ciger A. Humoral and cellular immune parameters in untreated and phenytoin or carbamazepinetreated patients. Int J Immunopharmacol $199 \& ; 17(1 Y): 1 \cdot V 1-1 \cdot V V$.

1r. Gardinali M, Conciato L, Cafaro C, Agostoni A. Complement system in coronary heart disease, A review. Immunopharmacol $\left.1990 ; r \cdot: 1 \cdot 0_{-}\right) \mathrm{V}$. 
Irq J Pharm— Vol. ' ', No. ', r. 11 